音声言語医学 $57: 1-6,2016$

原 著

\title{
痤攣性発声障害に関する全国疫学調査
}

\begin{tabular}{|c|c|c|c|}
\hline 政光 ${ }^{1)}$ & 弘瀨 & ハほり1) & 長尾明日香 \\
\hline 真夏 & 大森 & 孝一2) & 城本 \\
\hline 典子4) & 久 & 育男5) & 英二 ${ }^{6}$ \\
\hline
\end{tabular}

要 約：本邦に扔ける痤攣性発声障害患者数や臨床像を明らかにすることを目的として, ア ンケート方式による疫学調查を実施した。本疾患の音声所見を収録したサンプル CD を作成し たうえで，全国の主要な耳鼻咽喉科医療機関 655 施設に調査表を送付した。その結果，過去 2 年間にこれらの医療機関を受診した患者は 1,534 例あり，このうち新規患者は 887 例 $(0.70$ 人 10 万人）いることが確認できた。これにより，有病率は 3.5 7.0 人/10 万人以上になるこ とが推測された。臨床像としては，年齢は 20 および 30 歳代が $59.0 \%$ を占め, 男女比は $1: 4.1$ と女性が多かった。病型は内転型が約 $93.2 \%$ を占め, 症状は内転型では声のつまりや努力性発 声，外転型では失声や声が抜けるなどが特徵的であった。症状発現から医療機関受診までの期 間の中央值は 3.0 年であった，治療は A 型ボツリ又ス毒素の内喉頭筋内注入療法や甲状軟骨形 成術 II 型などが，一部の医療機関で集約的に行われていた。今回の調査を通して, 痤攣性発声 障害は耳鼻咽喉科医においてもまだ十分に認識されていないことが推測された。調査結果など を基にして，診断基準の作成や治療指針の確立が望まれる。

索引用語：痤攣性発声障害, アンケート調査, 有病率, ボツリ又ス毒素注入療法

\section{Nationwide Survey of Spasmodic Dysphonia in Japan}

\author{
Masamitsu Hyodo ${ }^{1)}$, Kahori Hirose ${ }^{1)}$, Asuka Nagao"), Manatsu Yoshida ${ }^{1)}$, Koichi Omori ${ }^{2)}$ \\ Osamu Shiromoto ${ }^{3)}$, Noriko Nishizawa ${ }^{4)}$, Yasuo Hisa ${ }^{5)}$ and Eiji Yumoto ${ }^{6)}$
}

高知大学医学部耳鼻咽喉科 ${ }^{12}:=783-8505$ 高知県南国市岡豊町小蓮

福島県立医科大学医学部耳鼻咽喉科 ${ }^{2)}:$ \%960-1295 福島市光が丘 1 番地

県立広島大学保健福祉学部コミュニケーション障害学科 ${ }^{3)}$ : $=723-0053$ 広島県三原市学園町 1-1

北海道医療大学心理科学部言語聴覚療法学科 ${ }^{4} ：$ T002-8072 札幌市北区あいの里 2 条 5 丁目

京都府立医科大学医学部耳鼻咽喉科 ( ) $^{\text {： }}$ 602-8566 京都市上京区河原町通広小路上る梶井町 465

熊本大学医学部耳鼻咽喉科 ${ }^{6)}$ : $=860-8556$ 熊本市本庄 1-1-1

${ }^{1)}$ Department of Otolaryngology, Kochi Medical School: Kohasu, Nankoku-shi, Kochi 783-8505, Japan

${ }^{2}$ Department of Otolaryngology, Fukushima Medical University: 1 Hikarigaoka, Fukushima 960-1295, Japan

${ }^{3}$ Department of Communication Sciences and Disorders, Faculty of Health and Welfare, Prefectural University of Hiroshima: 1-1 Gakuen-cho, Mihara, Hiroshima 723-0053, Japan

${ }^{4}$ Department of Communication Disorders, School of Psychological Science, Health Sciences University of Hokkaido: Ainosato 2-jo 5-chome, Kita-ku, Sapporo, Hokkaido 002-8072, Japan

${ }^{5}$ Department of Otolaryngology, Kyoto Prefectural University of Medicine: 465, Kajii-cho, Kawaramachi-Hirokoji, Kamiyo-ku, Kyoto 602-8566, Japan

${ }^{6}$ Department of Otolaryngology, Kumamoto University: 1-1-1 Honjo, Kumamoto 860-8556, Japan

2015 年 3 月 2 日受稿 2015 年 4 月 27 日受理 


\begin{abstract}
We conducted a nationwide survey of spasmodic dysphonia (SD) in Japan with the aim of revealing the epidemiological and clinical features of SD. Questionnaires were sent to 655 major otolaryngological institutions with a data disc which included representative voice samples of SD. We identified 1,534 patients over a period of 2 years. Among them, 887 (0.77 patient/100,000 population) were new patients. Prevalence of the disease in Japan was estimated to be $3.5-7.0$ patients $/ 100,000$ population. The patients were predominantly 20-39 years in age (59.0\%) and female in gender (1: 4.1 male/female ratio). Adductor type accounted for $93.2 \%$ of the patients. Clinical symptoms were characterized by strangled or effortful speech in the adductor type, and whispered or breathy voice quality in the abductor type. The median interval between the onset of symptoms and the first hospital visit was 3.0 years. Treatments by botulinum toxin injection into the intrinsic laryngeal muscles or type 2 thyroplasty were aggregately performed at several hospitals. This study suggested that SD is not yet fully recognized even among otolaryngologists and that diagnostic criteria and a standard therapeutic guideline need to be established.
\end{abstract}

Key words: spasmodic dysphonia, questionnaire survey, prevalence of the disease, botulinum toxin injection

\section{はじめに}

痓攣性発声障害 (spasmodic dysphonia, 以下 SD)は, 発声器官に器質的異常や運動麻瘏を認めない機能性発 声障害の一つで, 発声時に内喉頭筋の不随意的, 断続 的な痓攣による発声障害をきたす。本症は内転型，外 転型，および両者が併存する混合型に分けられるが， 内転型では発声時に声带が内転することで発声中の呼 気流が遮断され, 声のつまりや途切れ, 努力性発声な どを呈する。一方，外転型は発声中に声門が開大する ことで息漏れ声や失声を呈する。いずれにおいても円 滑な会話が妨げられ，就業や社会生活においてきわめ て大きな支障をきたす ${ }^{11}$ 。しかし，本疾患の患者実態 は国内はもとより海外に扔いても十分にわかっておら ず，診断基準も確立されていない．このため，本疾患 は耳鼻咽喉科医においても十分に認知されているとは いいがたく，心因性発声障害などと混同され，患者は 複数の医療機関を転々と受診することも多い。このこ とから，今回われわれは全国調査により本疾患の実態 把握を行うとともに，その臨床像についても検討した ので報告する.

\section{方法}

本疾患は稀少で音声障害を専門としない耳鼻咽喉科 医では認識や臨床経験が少ないことが予想されるた め, まずアンケートに先立ち, 調査時の参考としても らうことを目的に代表的な患者の音声サンプル（内転 型 11 例，外転型 2 例）を収録した CD を作成した。

\section{1. 一次アンケート調査}

全国の日本耳鼻咽喉科学会専門医制度認可研修施設 （641 施設）ならびに SD 患者の診療実績を有すると 思われるその他の医療機関（14 施設）の計 655 施設 に対して，先に作成した音声サンプル $\mathrm{CD}$ とともにア ンケート用紙を送付した。この際，SDには現在のと ころ確立された診断基準がないため, 表 1 に示すよう な一般的な臨床所見を添付して回答の参考にしても らった。調査項目は 2011 年 10 月〜 2013 年 9 月の 2 年間に受診した SD の患者数（疑い患者を含む），お よびこれらの患者の年齢, 性別, および病型とした.

\section{2 . 二次アンケート調査}

一次アンケート調査にて, SD 患者(疑い患者を含む) の受診があると回答した医療機関を対象に二次アン ケート調査を行った，調査項目は，(1)患者の年齢・性 別, (2)病型 (内転型・外転型・混合型の別), (3)初診 · 再診の別，(4)主な症状，(5)症状発現から初診までの期 間，(6)初診までの他の医療機関受診の有無（ありの場 合にはその数)，(7)治療の有無とその内容，8他の医 療機関への紹介の有無（ありの場合にはその医療機関 名), (9) SD 診療に扔ける診断や治療などで問題と感 じている点についての自由記載，とした。 なお，本研 究は「疫学研究に関する倫理指針」(文部科学省・厚 生労働省，平成 20 年 12 月 1 日改正）に従い，高知大 学医学部附属病院倫理審査委員会の承認を受けたうえ で実施した。 
表 1 痤攣性発声障害の一般的臨床所見

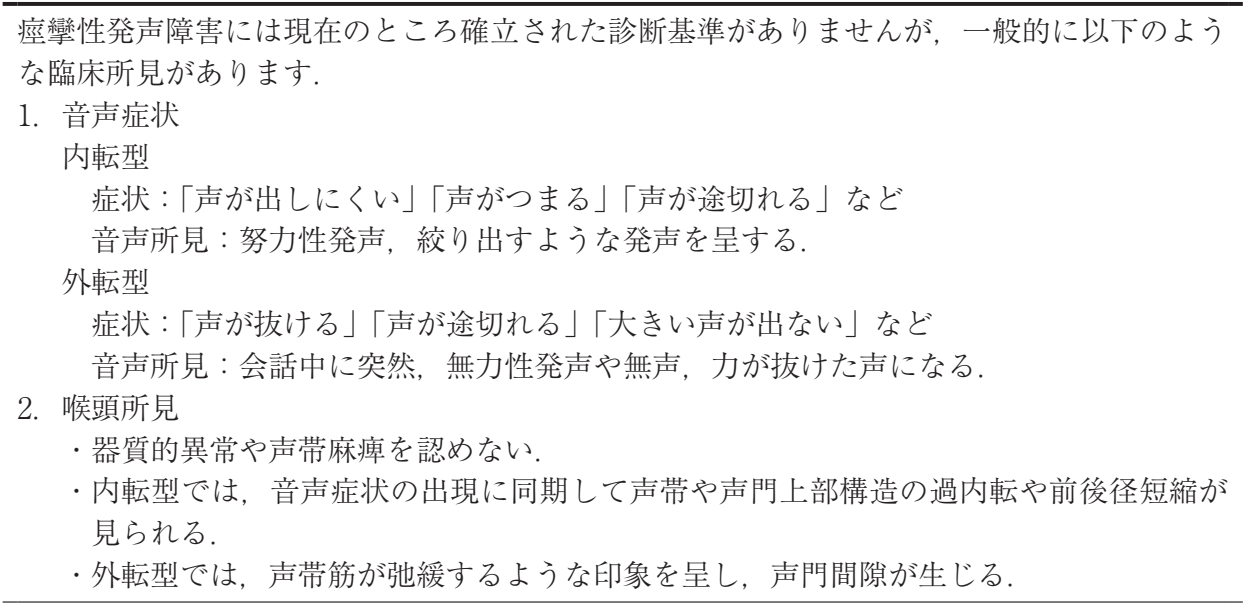

表 2 性別/病型別の患者数（例）

\begin{tabular}{crrr}
\hline 病型 & 男性 & 女性 & 合計 \\
\hline 内転型 & 273 & 1,157 & 1,430 \\
外転型 & 23 & 65 & 88 \\
混合型 & 2 & 14 & 16 \\
合計 & 298 & 1,236 & 1,534 \\
\hline
\end{tabular}

表 3 性別/病型別の平均年齢(歳)

\begin{tabular}{cccc}
\hline 病型 & 男性 & 女性 & 平均 \\
\hline 内転型 & 39.2 & 38.6 & 38.7 \\
外転型 & 37.8 & 43.8 & 42.2 \\
混合型 & 31.0 & 39.7 & 38.6 \\
平均 & 39.0 & 38.9 & 38.9 \\
\hline
\end{tabular}

回答の参考になるよう,一般的な症状および喉頭所見についての説明をアンケートに添付した．

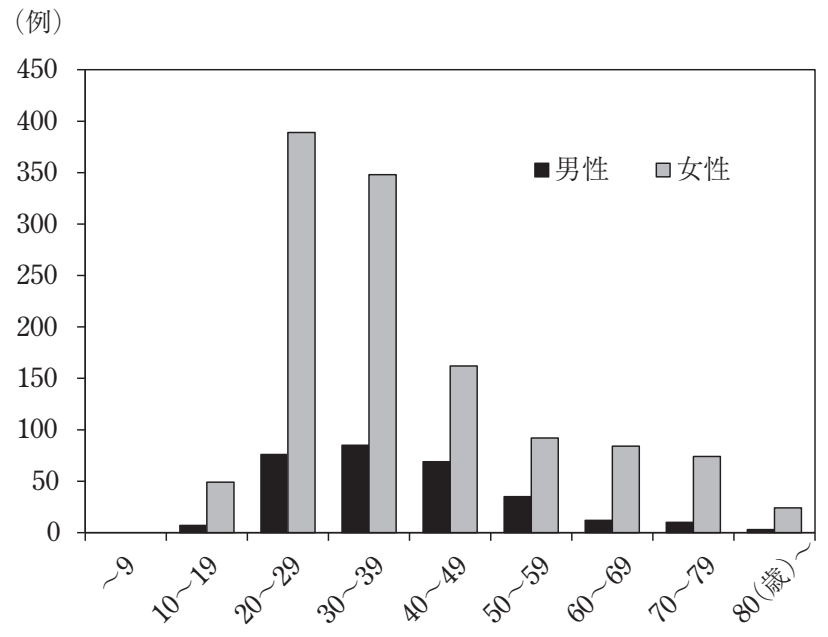

図 1 患者の年齢分布

20 歳台が最も多く, 20 および 30 歳台が全体の約 $60 \%$ を占める.

\section{結果}

\section{1. 一次アンケート結果}

369 施設より回答が得られた（回収率 56.3\%)。過去 2 年間の患者数は 0 例（最少） 457 例（最多）と施設 間でのばらつきがきわめて大きかった．患者数はの心゙ 1,746 例であったが，このうち詳細が不明な例や回答 者のコメントから診断が疑わしい例を除き，さらに病 型と性別を把握することができた例は1,534 例あった。 そこで，これらの例を対象に解析を行った。

患者の性別は男性 298 例 (19.4\%), 女性 1,236 例 (80.6\%) で, 男女比は約 1:4.1 と女性に多かった（表 2)。病型別では内転型 1,430 例 (93.2\%), 外転型 88 例 $(5.7 \%)$ ，混合型 16 例（1.0\%）であった。性別を病 型ごとに見ると, 内転型では男女比が $1: 4.2$ である のに対して, 外転型では $1: 2.8$, 混合型では $1: 7.0$ であり，外転型では内転型より男性の比率が高い傾向
表 4 病型別の主な症状（\%)

\begin{tabular}{lccc}
\hline \multicolumn{1}{c}{ 症状 } & 内転型 & 外転型 & 混合型 \\
\hline 声のつまり & 76.8 & 16.0 & 69.2 \\
嗄声 & 27.5 & 46.7 & 30.8 \\
声のふるえ & 22.0 & 12.0 & 38.5 \\
声の途切れ & 21.6 & 24.0 & 15.4 \\
努力性発声 & 12.2 & 1.3 & 0.0 \\
失声, 声が抜ける & 1.0 & 21.3 & 53.8 \\
\hline
\end{tabular}

にあったが有意差は認めなかった（Fisher の正確確 率検定, $\mathrm{p}=0.12)$.

次に患者の性別と年齢が把握できた 1,530 例につい て検討をした，年齢は 12〜91歳であり，平均年齢は 男性が 39.0 歳, 女性が 38.9 歳であり, 男女間では差 を認めなかった（表 3 )。病型別では内転型 38.7 歳, 外転型 42.2 歳, 混合型 38.6 歳であり, 有意差はない ものの外転型の年齢がやや高かった，年齢別では 20 歳台が $30.5 \%$ と最多で，次いで 30 歳台が $28.5 \%, 40$ 歳台が $15.2 \%$ の順であった（図 1)。その結果，20 お よび 30 歳台が $59.0 \%$ と全体の半数以上を占めた。男 女別および病型別での年齢分布には大きな差はなかっ た。

\section{2. 二次アンケート結果}

1,282 例についての回答が得られた（回収率 $73.4 \%$ ). 症状（複数回答あり）について集計すると（表 4), 内転型では声のつまりが最も多く $76.8 \%$ の例に認 められた. 次いで嗄声, 声のふるえ, 声の途切れなど がそれぞれ 20〜30\%の例に見られた。一方，外転型 では嗄声が $46.7 \%$ と最も多く, 次いで声の途切れや失 声が比較的多く見られた。内転型と外転型の症状を比 較すると，内転型では声のつまりや努力性発声が外転 型より多く，一方，外転型では失声や声が抜けるなど 


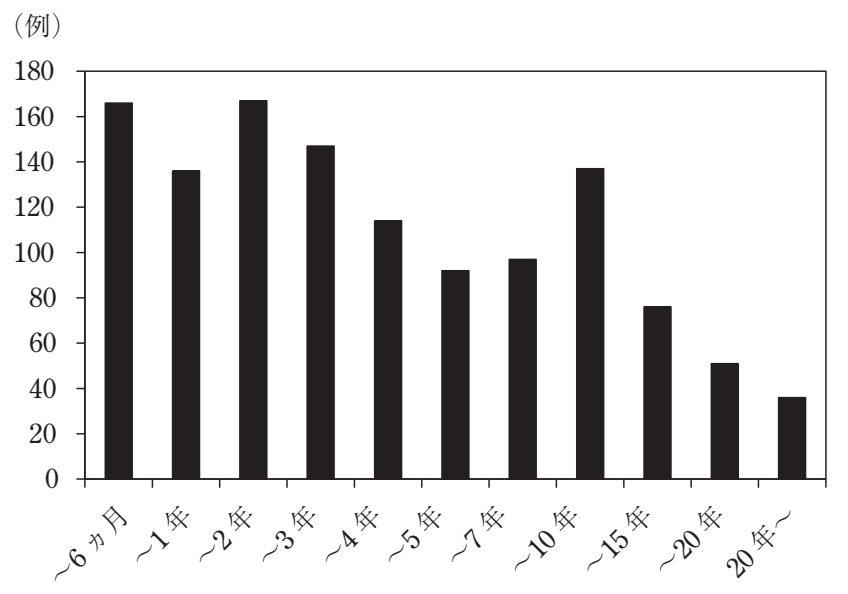

図 2 医療機関受診までの罹病期間 2 年以内が約 38\% を占めるが, 10 年以上の例も約 $20 \%$ いる.

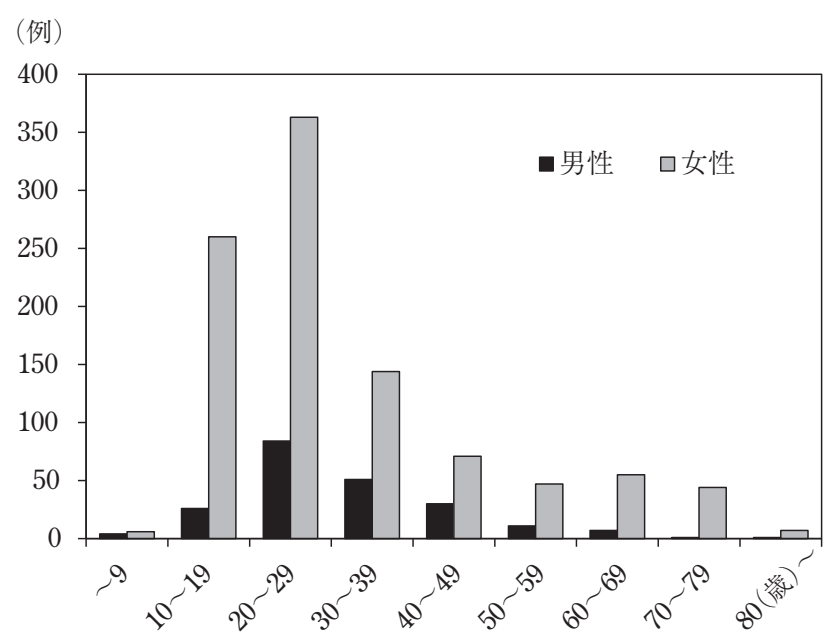

図 3 発症時年齢

20 歳台が最も多く, 次いで 10 歳台が多い

の症状が内転型と比較して多かった。

症状発現から医療機関受診までの期間は 1 カ月〜 46 年ときわめて幅があり, 中央值は 3 年 0 カ月であった (図 2).10 年以上の例も $20.9 \%$ に及んだ。各医療機関 を受診するまでに，76.0\%の患者は過去に他の医療機 関の受診歴があった。なかには約 20 年間に 30 以上の 医療機関を受診していた患者もいた。年齢と罹病期間 から発症年齢を算出すると（図 3), 20 歳台の発症が $36.9 \%$ と最も多く, 次いで 10 歳台であり, 平均 30.9 歳であった。男女別では男性 31.0 歳, 女性 30.8 歳で 差はなかった。調查期間内に各医療機関を初診した患 者は 1,054 例であった。このうち, 他の医療機関へ紹 介された患者は 167 例あった。これらの例は重複して いると考えてそれを除することで，調査対象とした 2 年間の新規患者数は 887 例と推計した.

治療では $86.3 \%$ の患者がSD に対して何らかの治療 を受けていた（図 4)。治療内容は重複を含めて, 内

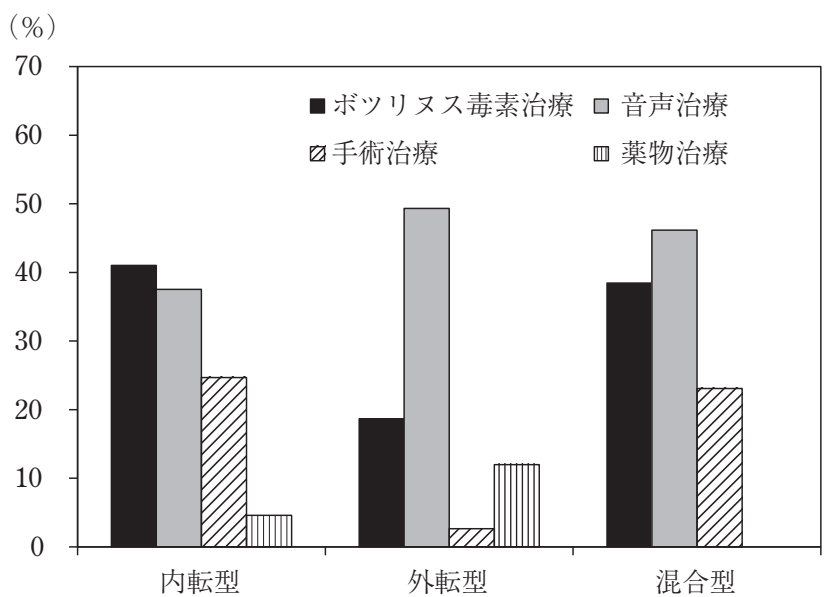

図 4 治療内容

内転型では約 40\%の例がボッリヌス毒素治療を, 約 25\% の例 が手術治療を受けていた。

転型では A 型ボツリヌス毒素の内喉頭筋内注入療法 が最も多く $41.0 \%$, 次いで音声治療が $37.5 \%$, 手術治 療が $24.7 \%$ であった，手術治療では甲状軟骨形成術 II 型が 92.6\% と大半を占め, 一部の例に対しては甲状披 裂筋切除術も行われていた。一方，外転型では音声治 療が $49.3 \%$ と多かったが, ボッリ又ス毒素治療は $18.7 \%$, 手術治療は $2.7 \%$ と少なかった。ボッリ又ス毒 素治療や甲状軟骨形成術 II 型の手術治療の大半は, そ れぞれ数施設で集約的に行われていた、マイナートラ ンキライザーや筋緊張緩和薬などによる薬物治療は全 体の $5.0 \%$ の例に対して行われているのみであった。

\section{考察}

$\mathrm{SD}$ の有病率や罹患率に関する疫学調查の報告は, 国内外を通じてもきわめて限られている. Konkiewitz ら2)はミュンヘン市に扮けるジストニアの疫学調查を 行い, そのなかで $\mathrm{SD}$ の有病率について, 人口 10 万 人当たり 1.0 人 (95\% 信頼区間：0.4-1.5人）と報告し た.しかし,この調查はミュンヘン市内にある 2 大学 にジストニアに対するボッリヌス毒素治療目的で受診 した患者のうち, 発声障害を有する患者数から求めた ものである。限られた地域での調査であり, ボッリヌ 久毒素治療目的で受診していない例は含まれていない 可能性がある。アメリカでは，ジストニア患者（29.5 人 10 万人）の約 $22 \%$ に声の異常があったとの疫学 調査結果 ${ }^{3)}$ から, SD の有病率が人口 10 万人当たり 5.2 ～6.5 人との推計がある ${ }^{4)}$. 本邦では, 山崎5) が全国の 81 大学病院を対象としたアンケート調查により 5 年 間に 224 例の SD 患者受診があったと報告した。さら に同時期の喉頭癌，突発性難聴，およびベル麻痺の調 
査医療機関における年間新規患者数も調査し，全国の それぞれの年間発症者数が 10 万人当たり 4.8 人, 10 〜20人，および 20 30人であることから，SDの罹 患率は人口 10 万人当たり喉頭癌からは 0.29 人, 突発 性難聴からは 0.77 人, ベル麻疩からは 0.94 人と推定 した ${ }^{5)}$. しかし，これも一部の医療機関を対象とした アンケート調査から推計したものであり正確性には欠 ける5).

今回, 全国の主要な耳鼻咽喉科医療機関を対象とし て本疾患に関する疫学調查を実施した，対象とした医 療機関は, 日本耳鼻咽喉科学会専門医制度認可研修施 設のすべてと，SDの診療実績があると考えられたそ の他の医療機関 14 施設である。これにより，SD 患 者の大半は把握できるものと考えた。その結果， 2 年 間に全国の耳鼻咽喉科医療機関で診療を受けた SD 患 者は，疑い例を含めてのべ 1,700 例あまりで，確実と 思われる例に限っても 1,534 例あった. 男女比は $1: 4.1$ (内転型は $1: 4.2$, 外転型は $1: 2.8)$ であったが, 山崎 5 は $1: 4.4$ (内転型は $1: 5.4$, 外転型は $1: 1.3$ ), 熊田ら ${ }^{6}$ は $1: 4.1$ (内転型）であったと報告して抢り，今回の 結果も女性が男性の約 4 倍という点で一致し, 病型別 でも外転型は内転型より男女差が少ない点で同様で あった。一方, 海外では内転型に打ける男女比が, Aronson $ら^{7)}$ は 1:1.1, Blitzer ${ }^{8)}$ は 1:1.7, Tisch ら ${ }^{9)}$ は $1: 1.6$ と報告しており，いずれも本邦での結果と 比べて男女差が少ない，本疾患の罹患率に人種差があ るのか，あるいは本邦では女性のほうが音声障害を主 訴として医療機関を受診する機会が男性と比較して多 いという社会的要因によるものかについては，今後の 検討が必要である。

年齢は男性が平均 39.0 歳, 女性が 38.8 歳とほとん ど差はなかったが, 病型別では内転型よりも外転型の ほうがやや年齢が高い傾向にあった。年齢分布では 20 歳台が最も多く, 20 および 30 歳台が全体の約 60\% を占めていた。また, 発症年齢も 20 歳台が最も多く, 山崎らの報告 ${ }^{4,5)}$ と同様であった。このように若年女 性に多いことが本疾患の特徵といえる。病型は内転型 が $93.2 \%$ と大部分を占め, 外転型は $5.7 \%$ にすぎなかっ た，讃岐ら ${ }^{10)}$ も本邦におけるアンケート調査の結果， 内転型が 95.7\% であったと報告しており同様の結果で あった。ただし，外転型は内転型と比較して音声障害 の特徵が非典型的であり，診断の困難さがかかわって いる可能性はある。今後, 本疾患の音声の特徵を臨床 医に対して広く周知して，より正確な診断につなげる 必要があると思われる。
アンケート二次調査では，患者の症状や医療機関の 受診動態について検討した。症状は，内転型では声の つまりを訴える患者が最も多く，また声の途切れや努 力性発声も多く認められた。一方, 外転型では声のつ まりや努力性発声はほとんど認められず, 声の途切れ, 失声, 声が抜ける，息がもれるなどの症状を呈する例 が多かった。また，声の翻転（声の裏返り）を呈する 例もあり, 外転型に特徵的な症状の一つと考元られる. このような音声の特徵を認識しておくことが，本症を 診断するうえで重要と思われる。

罹病期間の中央值は 3 年 0 カ月であり，医療機関受 診までに長期間を要していることが明らかになった。 実際, 76\%の例は過去に他の医療機関の受診歴があり， 10 年以上にわたる例も約 $20 \%$, 最長で 46 年の例もあっ た。その原因として，診断の困難さという医療機関側 の要因とともに, 発声障害以外の症状にそしいため患 者自身が「声が出しにくかったが病気であるとは思わ なかった」「精神的なものだと思っていた」「声の使い すぎだと思っていた」などと考えていた患者側の要因 も指摘されている1). 社会に対する SD の啓発活動も 必要であろう。

さて，今回の調査を基にして，本邦における $\mathrm{SD}$ 患 者数を推計してみる。本調査の結果, 重複例を除いて 2 年間に全国の医療機関を受診した新規患者数は 887 例であった． 1 年間では約 450 例となり， 2013 年の本 邦の人口（約 1 億 2,730 万人）と比較すると，人口 10 万人あたりの罹患率は 0.35 人となる。これは，山崎 $ら^{4,5)}$ が喉頭癌患者数との比較から推計した罹患率よ りは多く, 突発性難聴患者数から推計した罹患率より は少ない，本症の自然経過に関する報告はないが，自 然治癒がなく罹患率が一定と仮定すると，全国での累 積患者数 (有病者数) は 10 年間で約 4,500 人 $(3.5$ 人 10 万人), 20 年間で約 9,000 人 $(7.0$ 人 $/ 10$ 万人) にな

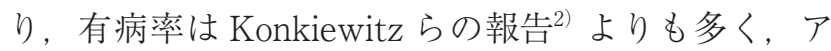
メリカでの推計值)にに打抄むね一致する。

本調査から明らかになったことの一つに，SDに対 する認識が耳鼻咽喉科医のなかでも随分と差があるこ とが挙げられる。たとえばわれわれが所属する高知県 では今回， 2 年間で 7 例の患者があった。一方，より 多くの人口を有しながら患者数が 0 名の県もあった。 本疾患に対する認識が一部の地域あるいは医療機関に おいてはまだ十分ではなく，讃岐ら ${ }^{10)}$ も指摘してい るように，本症の診断にいたっていない患者も少なく ないためと考えられる。このことからすると実際の $\mathrm{SD}$ 患者数は先の推計よりさらに多くなる可能性があ 
る。本調査にあたって，われわれは SD の代表的な音 声サンプルを収録した CD を作成した。この CD は本 疾患に対する認識を深めることにもつながると期待し ている.

治療では約 40\% の例がボッリ又久毒素の局所注入 療法を, 約 25\%の例が甲状軟骨形成術 II 型をはじめ とする外科的治療を受けていた。一次アンケートで 100 例を超える患者の診療を行っていると回答した医 療機関が 3 施設あったが, これらはいずれもボッリ又 久毒素の局所注入療法を積極的に実施している施設で あった。また，甲状軟骨形成術も大半が限られた数カ 所の医療機関で実施されていた。音声治療は $40 \%$ 近 い例に対して行われていたが，これには簡単な発声指 導なども含まれており，一定の訓練プログラムに沿っ て行われたものばかりではない.

2001 年に山崎5) が報告した疫学調査と本調査の治 療内容を比較すると興味ある変化が見られる。山崎の 報告では，ボツリ又ス毒素治療を受けていた例は約 1/4で, 手術治療は $10 \%$ にも満たなかった。一方, 本 調査ではいずれの治療も大幅に増えていた。これらの 治療法の有効性が, 医療関係者や患者の間で徐々に浸 透しつつあるためと思われる6,8,9,11). しかし, 先に述 ベたようにこれらの治療は一部の医療機関で集約的に 行われているのみであった，裏を返せば一般の医療機 関で標準的に実施できる治療法が確立されていないと いうことでもある。アンケートの自由記載でも，診断 基準がなく心因性発声障害や他の機能性発声障害との 鑑別が難しいこと, 治療の適応基準がないこと, 治療 を実施できる医療機関が限られていることなどの意見 が多数あった，本調査を基にして，本症に対する治療 指針の確立や治療法の標準化に向けたエビデンスの集 積が望まれる。

\section{まと め}

$\mathrm{SD}$ 患者数や臨床像を明らかにすることを目的とし て, 全国の主要な耳鼻咽喉科医療機関 655 施設を対象 としたアンケート調查を実施した。 その結果, 過去 2 年間に全国で少なくとも 887 例 $(0.70$ 人 $/ 10$ 万人）の 新規患者がいることが確認でき，全国での有病者数は 少なくともその数倍以上に及ぶと推計した。臨床像と しては, 20 および 30 歳台が約 60\%, 男女比は 1:4.1, 病型では内転型が約 93\%を占めていた。症状では内 転型は声のつまりや努力性発声, 外転型は失声や声が 抜けるなどが特徵的であった。治療は, ボッリ又ス毒
素の内喉頭筋内注入療法や甲状軟骨形成術 II 型なと が, 限られた医療機関で集約的に行われていた。 今後, 本疾患に対する診断基準の作成や治療指針の確立が望 まれる。

本論文について申告すべき利益相反はない．

本研究は平成 25 年度厚生労働科学研究費補助金: 難治性疾 患等克服研究事業（難治性疾患克服研究事業）「痓攣性発声障 害に関する調查研究」(H25-難治等（難)-一般-003）により実 施した。アンケート調查にご協力いただいた医療機関ならびに 関係各位に深謝いたします。

\section{文献}

1）椎葉由佳：患者の抱える問題. 痤攣性発声障害一そのメカ 二ズムと治療の現状 (小林武夫編), 時空出版, 東京, 92107 頁, 2005.

2) Konkiewitz EC, Trender-Gerhard I, Kamm C, et al: Survice-based survey of dystonia in Munich. Neuroepidemiology, 21: 202-206, 2002.

3) Rosenfield DB: Clinical aspects of speech motor compromise. Therapy with Botulinum Toxin (edited by Jankovic J and Hallett M), Marcel Dekker, New York, 1994.

4）山崎竜一, 小林武夫：日本における痤攣性発声障害の罹患 率. 病攣性発声障害一そのメカニズムと治療の現状 (小林 武夫編), 時空出版, 東京, 112-115 頁, 2005 .

5) 山崎竜一：痤攣性発声障害の疫学的調査一アンケート調査 による検討一. 音声言語医学, $42: 343-347,2001$.

6）熊田政信, 小林武夫, 村野恵美, 他：ボッリヌストキシン 注射一小林武夫グループの 16 年 $(1989 \sim 2004)$ 一. 喉頭, $16: 67-73,2004$.

7) Aronson AE: Adductor spasmodic dysphonia. Clinical Voice Disorders (edited by Aronson AE), Thieme Inc, New York, pp 187-197, 1985.

8) Blitzer A: Spasmodic dystonia and botulinum toxin: experience from the largest treatment series. Eur J Neurol, 17 (Suppl 1): 28-30, 2010.

9) Tisch SHD, Brake HM, Law M, et al: Spasmodic dysphonia: clinical features and effects of botulinum toxin therapy in 169 patients - an Australian experience. J Clin Neurosci, 10: 434-438, 2003.

10）讃岐徹治, 湯本英二：痤攣性発声障害の診断一アンケート 調査による検討一. 喉頭, $26: 81-85,2014$.

11) Sanuki Y, Yumoto E, Minoda R, et al: Effects of type II thyroplasty on adductor spasmodic dysphonia. Otolaryngol Head Neck Surg, 142: 540-546, 2010.

別刷請求先： $=783-8505$ 高知県南国市岡豊町小蓮 高知大学医学部耳鼻咽喉科 兵頭政光 